\title{
PERANAN KETERANGAN SAKSI SEBAGAI SALAH SATU ALAT BUKTI DALAM PROSES PIDANA
}

\author{
Oleh : Suisno \\ Dosen Fakultas Hukum Universitas Islam Lamongan
}

\begin{abstract}
ABSTRAK
Penyelesaian suatu tindak pidana sebagai perkara pidana merupakan rangkaian proses, akan tetapi selesai tidaknya suatu kasus pidana, sangat bergantung pada hasil Pemeriksaan Hakim di persidangan Pengadilan Negeri, Dalam acara pidana, sesuai dengan ketentuan pasal 184 Kitab Undang-undang Hukum Acara Pidana (yang selanjutnya disingkat dengan KUHAP).

Sebagaimana bunyi pasal 184 KUHP diatas, ada lima(5) alat bukti yang dapat dipergunakan dalam menyelesaikan perkara Pidana, akan tetapi peranan alat bukti dari alat- alat bukti tersebut hanya deperuntukan dalam proses pemeriksaan pengadilan.

Keterangan saksi merupakan salah satu alat bukti yang mempunyai kekuatan pembuktian kuat, utamanya dialami usaha untuk membuktikan perbuatan materiil pelaku tindak pidana, apabila saksi meninggal dunia sebelum perkara yang bersangkutan dimasukkan ke Pengadilan Negeri oleh Jaksa Penuntut Umum, maka kemungkinan besar Jaksa tidak lagi dapat membuat surat dakwaan.Demikian pula apabila saksi belum memberikan keterangan di Persidangan ternyata meninggal dunia.
\end{abstract}

Kata Kunci : Keterangan Saksi, Alat Bukti,Proses Pidana.

\section{A. Pendahuluan.}

\section{Latar Belakang Masalah}

Walaupun seorang pelaku tindak pidana telah dapat ditangkap, atau tertangkap tangan misalnya, maka prosedur acara pidana dalam penyelesaian kasus yang bersangkutan guna menentutkan pidana yang akan di jatuhkan terhadap pelakunya, tetap harus dipatuhi. Walaupun dengan jelas diketahui, pelaku tindak pidana tertangkap tangan dan mengakui perbuatannya, akan tetapi guna penyalesaiannya, utamanya di Pengadilan Negeri alat-alat bukti yang diperlukan tetap diupayakan dandipergunakan.

Yang dapat menentukan salah atau tidaknya seorang pelaku tindak pidana, hanyalah Hukum. Itupun setelah mempertimbangkan alat-alat bukti yang sah dan berkaitan dengan tindak pidana yang dilakukan pelaku yang bersangkutan.

\begin{abstract}
Penyelesaian suatu tindak pidana sebagai perkara pidana merupalan rangkaian proses, akan tetapi selesai tidaknya suatu kasus pidana, sangat bergantung pada hasil Pemeriksaan Hakim di persidangan Pengadilan Negeri, Dalam acara pidana, sesuai dengan ketentuan pasal 184 Kitab Undang-undang Hukum Acara Pidana (yang selanjutnya disingkat dengan KUHAP). yang dapat dipergunakan sebagai alat bukti adalah:
\end{abstract}

(1) Alat bukti yang sah, ialah :
a. Keterangan Saksi,
b. Keterangan Ahli,
c. Surat,
d. Petunjuk,
e. Keterangan terdakwa.

(2) Hal-hal yang secara umum sudah diketahui tidak perlu dibuktikan. ${ }^{1}$

${ }^{1}$ KUHAP, Kitab Undang-undang Hukum Acara Pidana, Undang-undang RI Nomor 8 Tahun 


\section{Perumusan Masalah}

Dengan Latar Belakang

Nampak bahwa usaha penanggulangan terhadap terjadinya tindak pidana, dilakukan secara preventif maupun represif. Preventif dilakukan dengan langkah-langkah pencegahan, antara lain seperti dilaksanakannya penyuluhanpenyuluhan hukum, Jaksa masuk Desa, dan lain-lain sejenisnya, sedangkan secara represif dilakukan dengan menindak para pelaku tindak pidana. Penindakan ini biasanya dilakukan dengan suatu rangkaian proses penyelesaian perkara pidana, sejak dari Penyelidikan dan atau Penyidikan, Penuntutan dan akhirnya dengan Pemeriksaan di Pengadilan Negeri.

Sebagaimana bunyi pasal 184 KUHAP di atas, ada lima alat bukti yang dapat dipergunakan dalam penyelesain perkara pidana, akan tetapi peranan alat bukti dari alat-alat bukti tersebut hanya diperuntukkan dalam proses pemeriksaan Pengadilan.

Salah satu alat bukti sebagaimana dikemukakan pada isi pasal 134 KUHAP tersebut di atas, adalah Keterangan Saksi. Dalam keterangan saksi ini selalu dikemukakan apa yang dilihat, dialami dan atau yang didengar" ${ }^{2}$ oleh saksi yang bersangkutan. Seorang saksi yang memberikan keterangan karena "pendengarannya dari orang lainnya" disebut dengan Testimonium de auditu.

Sebagaimana alat-alat bukti yang lain, maka keterangan saksi merupakan suatu alat bukti yang juga penting bahkan yang sering dipergunakan pada setip kasus, melebihi kuantitasnya dibandingkan dengan alat-alat bukti lainnya.

1981 dan Penjelasannya, Simplex, Jakarta, 1988, halaman 79

2 Andi Hamzah, Pengantar Hukum Acara Pidana Indonesia, Ghalia Indonesia, Jakarta, halaman 236-240
Permasalahan di atas, maka perumusan masalah yang diketengahkan dalam skripsi ini, adalah :

a. Bagaimanakah kekuatan alai bukti Keterangan Saksi dalam pembuktian pada proses penyelesaian perkara pidana?

b. Apa hambatan-hambatan dalam penggunaan keterangan saksi dalam pembuktian perkara pidana?

\section{Tujuan Penelitian}

Adapun tujuan yang ingi dicapai dalam penelitian ini adalah sebagai berikut:

1. Ingin mengetahui bagaimana peranan saksi atau kekuatan bukti saksi dalam proses penyelesaian perkara pidana di Pengadilan Negeri.

2. Ingin mengetahui bagaimana hambatan-hambatan dalam penggunaan keterangan saksi dalam pembuktian perkara pidana.

B. Kajian Teori

\section{Pengertian Alat Bukti dan Keterangan Saksi \\ Alat bukti berkaitan} dengan pembuktian. Pembuktian, utamanya dalam suatu penyelesaian kasus pidana, bermacam-macam pengertiannya, walaupun pada dasarnya akan dapat ditemukan kesamaannya.

Menurut Van Eammelen, membuktikan berarti melalui pemeriksaan dan pertimbangan untuk mendapatkan suatu kepastian yang patut atau layak bagi hakim tentang mengapa paristiwa ituterjadi. SM. Amin berpendapat, bahwa membuktikan berarti berusaha memperoleh suatu kepastian tentang suatu kenyataan, yaitu kepastian yang menimbulkan keyakinan hakim. 
Ada pula pendapat lain, yaitu pendapat R. Subekti, yang menyatakan bahwa membuktikan berarti meyakinkan hakim tentang kebenaran dalil-dalil yang dikemukakan dalam persengketaan.

Dengan demikian, membuktikan, diartikan sebagai suatu usaha memberikan gambaran kepada Hakim tentang adanya suatu peristiwa atau keadaan yang menggunakan alatalat yang disebut dengan alat bukti serta menurut cara-cara yang ditentukan oleh Undang-undang, sehingga apakah suatu peristiwa sungguh-sungguh terjadi dan dengan demikian Hakim memperoleh suatu keyakinan bahwa peristiwa atau keadaan itu sungguh-sungguh terjadi atau tidak.

Usaha membuktikan sebagaimana diuraikan di atas juga mempunyai sistem tertentu. Sistem pembuktian yang kita kenal ada 3 (tiga) macam, yaitu :

1. Sistem Positif wettelijk,

2. Sistem Negatif wettelijk, dan

3. Sistem pembuktian Berdasarkan Keyakinan Hakim.

ad. 1. Sistem Positif Wettelijk,

Dalam sistem ini mendalilkan, bahwa hakim hanya boleh menentukan kesalahan terdakwa, apabila sudah ada bukti, minimum yang diperlukan oleh Undangundang. Apabila bukti minimum tersebut telah terbukti ada dan sah, Maka Hakim harus dan wajib menyatakan kesalahan terdakwa, walaupun Hakim sendiri belum yakin atau memperoleh keyakinan akan kebenaran kesalahan terdakwa.

ad. 2. Sistem Negatif wettelijk,

Wirjono Prodjodikoro menyebut sistem pembuktian ini sebagai "Sistem pembuktian menurut Undang-undang sampai suatu batas". ${ }^{3}$

Sistem pembuktian ini didasarkan pada alat-alat bukti yang sah menurut Undang-undang. Dalam pembuktian ini, hakim hanya diperbolehkan untuk menggunakan alat bukti yang telah disebutkan da1am Undang-undang.

ad. 3. Sistem Pembuktian Melulu Berdasarkan Keyakinan Hakim,

Sistem Pembuktian ini sangat subyektif sekali sifatnya, karena untuk menentukan salah dan tidaknya terdakwa, hanya diperlukan adanya keyakinan hakim ada bukti atau tidak, karenanya sistem ini tidak diberlakukan di Indonesia.

\section{Fungsi Keterangan Saksi Dalam Pembuktian Perkara Pidana}

Sebagian besar pemeriksaan perkara pidana memang dilakukan dengan menggunakan alat bukti saksi.

Dikaitkan dengan ketentuan pasal 378 KUHP, yang bunyi selengkapnya adalah sebagai berikut :

\footnotetext{
${ }^{3}$ Ibid, halaman 92
} 
Barang siapa dengan maksud menguntungkan diri sendiri atau orang lain secara melawan hukum dengan memakai nama palsu atau martabat palsu, dengan tipu muslihat atau rangkaian kebohongan, menggerakkan orang lain untuk menyerahkan barang sesuatu kepadanya, atau supaya memberi hutang maupun menghapuskan piutang, diancam karena penipuan dengan pidana penjara paling lama empat tahun. ${ }^{4}$

Maka kaitan perbuatan terdakwa dengan unsur-unsur pasal 378 KUHP tersebut, adalah sebagai berikut :

1. Dengan maksud menguntungkan diri sendiri, ataupun untuk orang lain.

Perbuatan terdakwa Sumarni melakukan penipuan kalung emas, memang dilakukan untuk menguntungkan dirinya secara pribadi.

2. Melawan hukum,

Unsur melawan hukum ini, di samping kesengajaan terdakwa juga melakukan pengambil alihan hak milik atas kalung emas 22 karat. 3100 gram tanpa "levering" yang sah, karena secara diam-diam menukar kalung imitasinya dengan kalung emas asli milik toko.

3. Dengan memakai nama palsu, atau martabat palsu

Dengan tipu muslihat atau rangkaian kebohongan, yang nampak pada perbuatan terdakwa dalam kasus pertamaini adalah "tipu muslihat", karena pura-pura membeli dan melihat-lihat

4 R. Soesilo, KUHP, Kitab Undangundang Hukum Pidana Lengkap Beserta Komentarkomentarnya Pasal Demi Pasal, Politeia, Bogor, 1983, halaman 120 kalung, akan tetapi kemudian menukarnya tanpa sepengetahuan pelayan/pemilik toko.

4. Menggerakkan orang lain untuk menyerahkan barang sesuatu kepadanya, atau supaya memberi utang atau menghapuskan piutang.

Perbuatan terdakwa di sini adalah "menggerakkan hati orang lain untuk menyerahkan barang sesuatu kepadanya.", karena dengan menukar kalung imitasi yang dibawanya dari rumah, maka "seolah-olah pelayan toko memberikan kalung aslinya" walaupun tanpa disadarinya.

Dari kasus sebagaimana diuraikan di muka, maka kewajiban hakim adalah untuk membuktikan dan kemudian meyakini kebenarannya, terhadap :

1. Maksud menguntungkan sendiri dari terdakwa,

2. Melawan hukum

3. Dengan memakai nama palsu, atau martabat palsu. kepadanya.

4. Menggerakkan hati orang lain .

C. Metode Penelitian.

1. Tipe Penelitian.

Tipe penelitian hukum yang dilakukan adalah yuridis normatif (hukum normatif). Metode penelitian hukum normatif adalah suatu prosedur penelitian ilmiah untuk menemukan kebenaran berdasarkan logika keilmuan hukum dari sisi normatifnya. ${ }^{5}$

5 Johnny Ibrahim, Teori \& Metode Penelitian Hukum Normatif, Banyumedia Publishing, Malang 2006, h..57 
Oleh karena itu penelitian hukum ini difokuskan untuk mengkaji penelitian hukum tentang kaidahkaidah atau norma-norma dalam hukum positif, yakni norma hukum yang terkait dengan kekuatan keterangan saksi di persidangan.

2. \begin{tabular}{lr}
\multicolumn{2}{c}{ Pendekatan Masalah } \\
Pendekatan & yang \\
dilakukan dalam penelitian ini \\
menggunakan & pendekatan \\
perundang-undangan & (statue
\end{tabular} approach). Pendekatan perundang-undangan adalah pendekatan yang dilakukan oleh peneliti melalui aturan perundang-undangan yang berkaitan dengan materi yang dibahas yaitu mengenai kekuatan keterangan saksi di persidangan. Selain itu juga digunakan pendekatan Kasus (Cass Approach). Pendekatan kasus digunakan untuk melihat kasus kasus yang terkait dengan keterangan saksi di persidangan.

\section{Bahan Hukum}

Dalam penulisan sekripsi ini penulis menggunakan bahanbahan hukum yang meliputi:

a. Bahan hukum primer:

Bahan hukum primer adalah merupakan bahan hukum yang bersifat autoritatif artinya mempunyai otoritas, bahan hukum terdiri dari perundangundangan, catatan resmi, atau risalah dalam pembuatan perundang-undangan dan putusan hakim. Adapun bahan hukum primer tersebut meliputi: Kitab Undang Undang Hukum Pidana (KUHP), Undang Undang
Nomor 8 Tahun 1981 tentang Kitab Undang Undang Hukum acara pidana (KUHAP).

b. Bahan Sekunder:

Bahan hukum sekunder adalah bahan yang diperoleh dari buku teks, jurnal-jurnal, pendapat para sarjana dan kasus-kasus hukum. ${ }^{6}$

4. Prosedur Pengumpulan Bahan Hukum

Baik bahan primer maupun bahan hukum sekunder dikumpulkan berdasarkan topik permasalahan yang telah dirumuskan dan diklasifikasi menurut sumber dan hirarkinya untuk dikaji secara komprehensif.

\section{Pengolahan dan Analisis Bahan Hukum}

Adapun bahan hukum yang diperoleh dalam penelitian adalah studi kepustakaan, aturan perundang-undangan, yang penulis uraikan dan dihubungkan sedemikian rupa, sehingga disajikan dalam penulisan yang lebih sistematis guna menjawab perumusan masalah yang dirumuskan. Cara pengolahan bahan hukum dilakukan secara deduktif yakni menarik kesimpulan dari suatu permasalahan yang bersifat umum terhadap permasalahan kongkrit yang dihadapi yakni kekuatan keterangan saksi di persidangan.

A. D. Hasil Penelitian dan Pembahasan.

1. Syarat-syarat yang Harus Dipenuhi Oleh Seorang Saksi dalam Proses Pembuktian Perkara Pidana

6 Peter Mahmud Marzuki. Penelitian Hukum. Universitas Air Langga. Surabaya. h. 15. 
Dalam setiap proses penyelesaian perkara pidana, siapa saja dapat menjadi saksi, kecuali apabila terkena pengecualian-pengecualian, sebagai berikut :

a. Bukan keluarga sedarah atau semenda dalam garis lurus ke atas atau ke bawah sampai derajad ke tiga dari terdakwa atau yang bersama-sama menjadi terdakwa.

b. Bukan saudara dari terdakwa atau yang bersama-sama sebagai terdakwa, saudara ibu atau saudara bapak, juga mereka yang mempunyai hubungan karena perkawinan, dan anak-anak saudara terdakwa sampai derajad ke tiga.

c. Bukan suami atau isteri terdakwa meskipun sudah bercerai atau yang belum bercerai, termasuk bagi yang bersama-sama sebagai terdakwa.

d. Bukan mereka yang karena harkat martabat maupun karena jabatannya, diwajibkan menyimpan rahasia, di mana pengecualian ini merupakan pengecualian relatif, dalam arti golongan ini dapat meminta pengunduran diri sebagai saksi, sepanjang alasan penolakannya diterima oleh Hakim. Misalnya :

Saorang dokter yang harus menyimpan rahasia penyakit pasiennya, yang kemungkinan akan berakibat fatal bagi si pasien tersebut akibat goncangan jiwa setelah mengetahui penyakit yang dtderitanya.

$\begin{array}{lr}\text { Seorang pastor agama } \\ \text { Katholik Roma. } & \text { Ini } \\ \text { berhubungan } & \text { dengan } \\ \text { kerahasiaan } & \text { orang-orang } \\ \text { yang telah } & \text { melakukan } \\ \text { pengakuan dosa } & \text { kepada } \\ \text { pastor tersebut. Sedangkan } & \text { Sang dimaksud dengan } \\ \text { martabatnya } & \text { dapat }\end{array}$

mengundurkan diri sebagai pastor. ${ }^{7}$

Paad golongan ini (nomor d), dapat mengundurkan diri sebagai saksi atau termasuk pengecualian relatif.

Ada juga golongan yang dapat memberikan keterangan, akan tetapi tidak disumpah. Di mana kekuatan buktinya digantungkan pada pendapat hakim yang arif dan bijaksana. Keterangan ini dapat dipergunakan sebagai bukti tambahan bagi Hakim apabila memang kaitannya dengan tindak pidana yang sedang diperiksa.

Mereka yang termasuk golongan ini, adalah :

a. Anak yang umurnya belum genap lima belas tahun dan belum pernah kawin,

b. Orang yang sakit ingatan atau sakit jiwa, meskipun ingatannya kadang-kadang baik kembali.

(Pasal 171 KUHAP) .

Sedangkan pasal 165 ayat (7) KUHAP, menyatakan sebagai berikut :

Keterangan saksi yang tidak disumpah meskipun sesuai dengan yang lain, tidak merupakan bukti namun apabila keterangan itu sesuai dengan keterangan dari saksi yang disumpah dapat dipergunakan sebagai tambahan bukti sah yang lain. ${ }^{8}$

\section{Kekuatan Keterangan Saksi Dalam Pembuktian Perkara Pidana}

Keterangan saksi memang merupakan alat bukti yang mempunyai kekuatan, utamanya sebagaimana

\footnotetext{
${ }^{7}$ Ibid, halaman 244

${ }^{8}$ Martiman Prodjohamidjojo, op.cit, halaman 21
} 
kebenaran materiil yang diperlukan hakim. Dengan keterangan saksi, perbuatan material terdakwa akan dapat disimpulkan kebenarannya.

Pada kasus pertama yang harus dibuktikan oleh hakim adalah :

a. Adanya tindak pidana penipuan

b. Benar-benar terdakwa bersalah melakukannya

Dengan demikian, keterangan saksi erat kaitannya dengan pembentukan keyakinan Hakim, apalagi ditambah dengan barang bukti dan keterangan terdakwa sendiri. Memang, prinsip "sekurang-kurangnya dua alat bukti" masih tetap dipegang, akan tetapi semakin banyak alat bukti yang ada, akan semakin meningkatkan keyakinan hakim terhadap kebenaran suatu tindak pidana dan kesalahan terdakwa.

\section{Hambatan-hambatan Dalam Penggunaan keterangan Saksi Dalam Pembuktian Perkara Pidana}

Sesuai dengan hasil wawancara dengan Hakim Pengadilan Negeri Bojonegoro, Poerwanto, SH, diperoleh pernyataan sebagai berikut :

Apabila saksi-saksi dalam suatu pemeriksaan perkaraa pidana dapat dihadirkan ke persidangan, maka permasalahan tidak pernah ditemukan. Karena bagi saksi warga negara asing, saksi tuli maupun saksi yang bisu dapat dimintai keterangan dengan penterjemah.

Permasalahan hanya muncul apabila saksi suatu parkara pidana tidak dapat didatangkan ke persidangan pengadilan, atau apabila saksi dimaksud juga melarikan diri, dan lain sebagainya. ${ }^{9}$

Dari hasil wawancara dengan Hakim Pengadilan Nageri Bojonegoro tersebut, maka dapat ditarik suatu pergertian bahwa hambatan-hambatan dalam menggunakan keterangan saksi di suatu persidangan pengadilan negeri, hampir tidak ditemui sama sekali. Satu-satunya hambatan hanya berkaitan dengan dapat atau tidaknya saksi yang bersangkutan didatangkan ke pemeriksaan pengadilan.

Sebagaimana diketahui, pemanggilan seorang saksi dilakukan dengan suatu "hal" tertentu. Pemanggilan seorang/beberapa orang saksi ke persidangan pengadilan memerlukan prosedur tertentu, antara lain :

1. Surat panggilan disampaikan kepada saksi di alamat/tempat tinggalnya, atau apabila alamatnya tidak diketahui, surat panggilan disampaikan ke kediaman saksi yang terakhir.

2. Apabila tidak ditemukan tempat tinggalnya, maka surat panggilan disampaikan kepada Kepala Desa di daerah hukum kemungkinan tempat tinggal saksi atau kediamannya yang terakhir.

3. Apabila saksinya ditahan, maka surat panggilan tersebut disampaikan kepada Kepala Lembaga Pemasyarakatan, atau Kepala Lembaga di mana saksi ditahan.

4. Penerimaan surat panggilan, baik oleh saksi langsung, orang lain maupun melalui orang lain harus disertai tanda terima.

5. Apabila kesemuanya itu masih belum dapat dilakukan maka surat panggilan ditempelkan di papan

9 Hasil Wawancara dengan Poerwanto, Hakim Pengadilan Negeri Malang, tanggal 20 April 1993 
pengumuman Pengadilan Negeri yang bersangkutan.

Kecuali apabila saksinya
ditahan, maka apabila setelah
disampaikannya surat panggilan
ternyata saksi tetap saja tidak datang,
atau saksi yang bersangkutan memang
"buron" atau melarikan diri, maka
Pengadilan akan menemui kesulitan
apabila saksi hanya seorang itu saja.

Secara keseluruhan, hambatan penggunaan keterangan saksi atau beberapa saksi di Pengadilan Negeri tidak menemui hambatan yang berarti, dan hambatan yang ada hanyalah apabila saksi yang bersangkutan ternyata tidak datang walaupun telah dipanggil secara sah.

\section{E. Penutup}

\section{A. Kesimpulan}

Dari keseluruhan pembahasan yang teIah dikemukakan pada halamahalaman terdahulu, maka kesimpulan yang diperoleh adalah sebagai berikut :

1. Keterangan saksi merupakan salah satu alat bukti yang mempunyai kekuatan pembuktian kuat, utamanya dalam usaha untuk membuktikan perbuatanmateriil pelaku tindak pidana .

2. Apabila saksi meninggal dunia sebelum perkara yang bersangkutan dimasukkan ke Pengadilan Negeri oleh Jaksa Penuntut Umum, maka kemungkinan besar Jaksa tidak lagi dapat membuat surat dakwaan. Demikian pula apabila saksi belum memberikan keterangan di persidangan ternyata meninggal dunia. Maka hakim juga kesulitan untuk menjatuhkan pidana terhadap pelaku. Kecuali apabila saksi telah salesai diperiksa di pengadilan dan kemudian meninggal dunia, maka kemungkinan Hakim dapat memutus perkara terdakwa yang bersangkutan. Dari keseluruhan kasus pidana yang diperiksa Pengadilan Negeri, sebagian besar selalu menggunakan alat bukti yang berupa keterangan saksi. Jarang sekali pemeriksaan perkara pidana di persidangan yang dilakukan tanpa keterangan saksi, baik itu saksi korban, saksi yang melihat dan atau saksi yang mendengar penyebab perkara pidana yang bersangkutan dari orang lain (testimonium de auditu). Dari keseluruhan saksi yang ada, maka saksi korbanlah yang sebenarnya merupakan saksi utama, sedangkan selanjutnya adalah saksi yang melihat tindak pidana dimaksud, kemudian testimonium de auditu.

\section{B. Saran-saran}

1. Walaupun di Indonesia masih jarang terjadi, maka saksi yang memberikan keterangannya untuk tindak-tindak pidana berat yang sedang diperiksa, perlu sekali memperoleh perlindungan hukum. Lembaga penegak hukum telah dibantu saksi, sehingga secara timbal balik harus pula menjamin keamanan pada saksi yang ada.

2. Pada masyarakat pedesaan, kewajiban menjadi saksi sebagaimana dimaksud merupakan suatu hal yang sangat menakutkan mereka. Untuk itu sangat perlu sekali dari pihak aparat penegak hukum memberikan penyuluhan terhadap warga pedesaan bahwa peranan mereka apabila dipanggil untuk memberikan keterangan saksi merupakan bantuan yang tidak kecil kepada pihak penegak hukum dalam memberikan 
bantuan penyelesaian perkara pidana di persidangan pengadilan yang merupakan kegiatan penanggulangan kejahatan secara represif.

\section{DAFTAR PUSTAKA}

\section{LITERATUR:}

Abdul Karim Nasution, Masalah Hukum Pembuktian Dalam Proses Pidana, Tanpa Penerbit, Jakarta, 1985.

Andi Hamzah, Pengantar Hukum Acara Pidana Indonesia, Ghalia Indonesia, Jakarta, 1988.

Departemen Kehakiman RI, Bahan Pokok Bagi Penyuluh Hukum, Undang-undang Hukum Acara Pidana dan Peraturan Pelaksanaannya, Jakarta 1985.

Djoko Prakoso, Alat Bukti dan Kekuatan Pembuktian didalam Proses Pidana, Liberty, Jogyakarta, 1988.

D. Simons, Beknopte Handleiding fot het wetboek van Strafordering, Haarlem : Derven F. Bohn' 25.

Hendrastanto Yudhowidagdo, et. all., Kapita Selekta Hukum Acara Perdata di Indonesia, Bina Aksara, Jakarta, 1988.

JM. Bammelen, Ons Straafrecht, Formele Strafrecht, Groningen : Tjenk Willink, 1977.

KUHAP, Kitab Undang-undang Hukum Acara Pidana, Undangundang RI Nomor 8 Tahun 1981dan Penjelasannya, Simplex, Jakarta, 1988.

Martiman Prodjohamidjojo, Sistem Pembuktian dan Alat-alat Bukti, Ghalia Indonesia, Jakarta, 1988.
Norman K Densin, Dikutip oleh Soerjono Soekanto, Pengantar Penelitian Hukum, Universitas Indonesia Press, Jakarta, 1987.

R. Tresna, Komentar HIR, Pradnya Paramita, Jakarta, 1989.

Soerjono Soekanti, Pengantar Penelitian Hukum, Universitas Indonesia Press, Jakarta, 1987.

\section{PERUNDANG UNDANGAN:}

Kitab Undang Undang Hukum Pidana (KUHP)

Undang Undang Nomor 8 Tahun 1981 tentang Kitab Undang Undang Hukum Acara Pidana (KUHAP 